\title{
Morphology and ecology of the bradoriid arthropods Spinospitella and Nikolarites from the Cambrian (Series 2, Stage 4) of North Greenland (Laurentia)
}

\author{
John S. Peel ${ }^{1}\left[\right.$ C Christian B. Skovsted ${ }^{2} \cdot$ Elise Wallet $^{1}$
}

Received: 9 January 2021 / Accepted: 25 May 2021 / Published online: 23 June 2021

(c) The Author(s) 2021

\begin{abstract}
Tuberculate fragments referred to Nikolarites spasskyi are compared with a complete carapace and other material of Spinospitella from Cambrian Series 2, Stage 4 in North Greenland. The descriptions expand earlier brief records from Laurentia of the two bradoriids, originally described from Siberia and Australia, respectively. The mutually exclusive occurrences of the two taxa indicate ecological control of their distribution in North Greenland. Robust fragments of Nikolarites spasskyi occur in reworked higher energy deposits of the Aftenstjernes $\varnothing$ Formation, while thin-walled carapaces of Spinospitella characterise deeper water mudstones within the Buen and Aftenstjernesø formations.
\end{abstract}

Keywords Bradoriida $\cdot$ Morphology $\cdot$ Ecology $\cdot$ Cambrian (Series $2 \cdot$ Stage 4) $\cdot$ North Greenland $\cdot$ Laurentia

\section{Introduction}

Trilobites, with their heavily mineralised exoskeletons, are easily the most conspicuous arthropods in the Cambrian, although localities with exceptional preservation, such as the lagerstätten of Chengjiang, Sirius Passet and the Burgess Shale (Briggs et al. 1994; Ineson and Peel 2011; Peel and Ineson 2011; Hou et al. 2017), with a wealth of lightly sclerotised forms, present a more accurate picture of arthropodan diversity. Widespread small bivalved shields or valves $(<10 \mathrm{~mm})$ grouped together as bradoriids also display high diversity evident through a variety of methods of preservation, although their position relative to other arthropod groups is largely unresolved (Hou et al. 2002, 2010;

Handling Editor: Mike Reich.

John S. Peel

john.peel@pal.uu.se

Christian B. Skovsted

christian.skovsted@nrm.se

Elise Wallet

elise.wallet@geo.uu.se

1 Department of Earth Sciences (Palaeobiology), Uppsala University, Villavägen 16, 75236 Uppsala, Sweden

2 Department of Palaeobiology, Swedish Museum of Natural History, Box 50007, 10405 Stockholm, Sweden
Williams et al. 2007; Zhai et al. 2019; McMenamin 2020). Most older records concern macrofossils that are often preserved in three dimensions, indicating the presence of robust shields (Ulrich and Bassler 1931; Siveter and Williams 1997; Hou et al. 2002). More recent studies focus on recovering phosphatic Small Shelly Fossils by digesting carbonates in weak acids, a process that may yield pristine faunas often displaying exquisite details of surface structures (Skovsted et al. 2006; Zhang 2007; Peel 2017a). In addition, the acid residues often contain broken and distorted bradoriid specimens demonstrating variation in the degree of phosphate mineralisation, be it primary or secondary, or postmortal effects such as exuviation, crumpling following ingestion by predators (Peel 2015) or taphonomic degradation. Fine details of surface sculpture may also be preserved in bradoriid assemblages of Small Carbonaceous Fossils retrieved by maceration of siliciclastic sediments in hydrofluoric acid, although the organic remains are commonly fragmented (Slater et al. 2018; Wallet et al. 2020).

Assemblages of Cambrian Stage 4 bradoriids from Greenland have been recovered from all three of these preservational windows. The macrofauna from the shelf mudstones of the Buen Formation at Brilles $\varnothing$ in south-eastern Peary Land (Fig. 1) includes specimens of the cambriid Petrianna fulmenata Siveter, Williams, Peel, and Siveter, 1996 almost $10 \mathrm{~mm}$ in length (Siveter et al. 1996; Peel and Willman 2018). It is associated with Aluta siku Peel and 


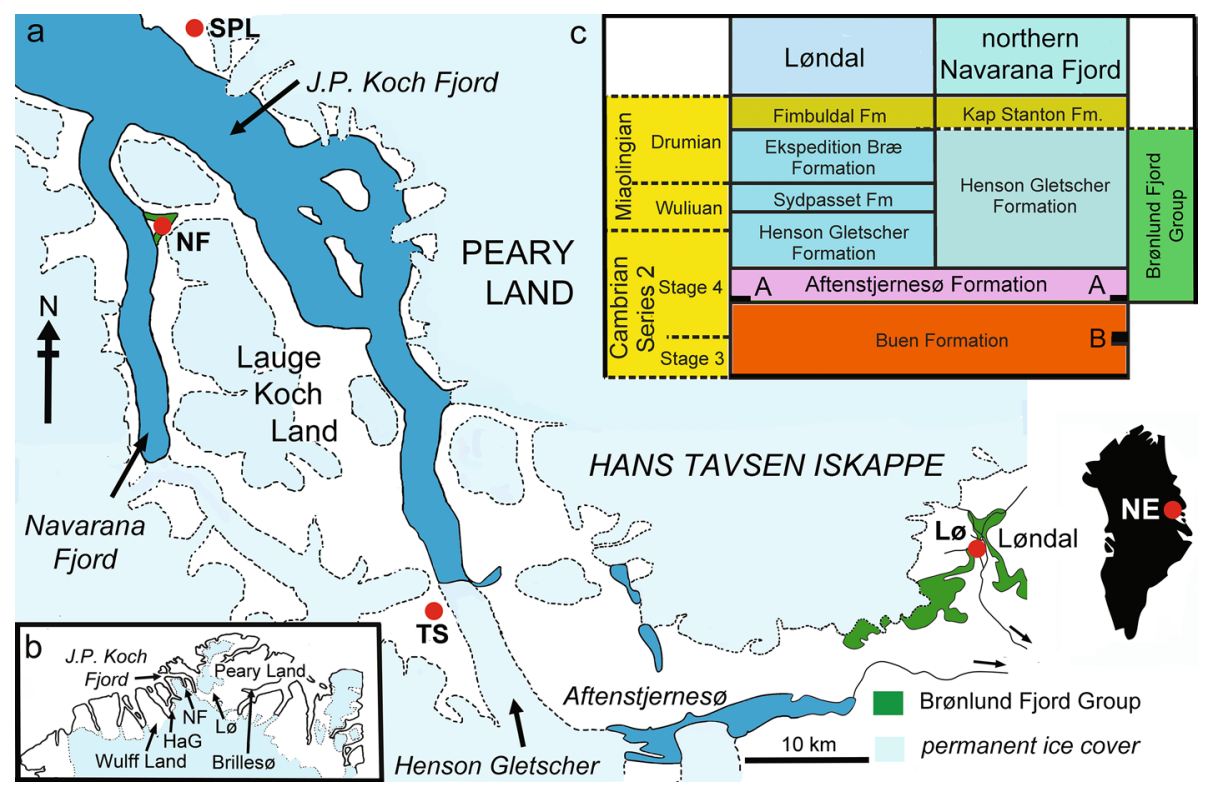

Fig. 1 Geography and geology. a Map of the western Peary LandLauge Koch Land area showing location of sample sites. Outcrop of Brønlund Fjord Group only shown at northern Navarana Fjord and Løndal: NE, North-East Greenland (inset map of Greenland); NF, Navarana Fjord locality; Lø, Løndal locality; SPL. Sirius Passet Lagerstätte; TS, type section of the Aftenstjernes $\emptyset$ Formation. b Map of North Greenland showing sample localities in the Aften-

Willman, 2018 and Indota? sp., the latter closer to Indiana Matthew, 1902 according to Streng and Geyer (2019), while fragments of several unidentified forms are also present (Peel and Willman 2018). Poorly preserved material assigned to Petrianna? sp. occurs in the highest beds of the Buen Formation (Peel and Willman 2018). Assemblages of Small Carbonaceous Fossils from the Buen Formation in the same outcrops contain fragments of several bradoriid taxa (Slater et al. 2018), including material recently assigned to Spinospitella Skovsted et al., 2006 (Wallet et al. 2020).

The Kap Troedsson Formation yielded well preserved phosphatised Hipponicharion skovstedi Peel, 2017a and Beyrichona avannga Peel, 2017a in assemblages of Small Shelly Fossils from southern Wulff Land (Fig. 1b). The fossils occur in a shallow ramp succession of lime mudstones and skeletal limestones that is equivalent to the more distal starved dolostone succession of the correlative lower member of the Aftenstjernes $\emptyset$ Formation of the J.P. Koch Fjord area (Fig. 1; Ineson and Peel 1997; Peel 2017a).

Small Shelly Fossils from the upper Henson Gletscher Formation in Løndal (Fig. 1) include rare bradoriids in limestones from the youngest parts of Cambrian Stage 4. Peel et al. (2016) and Peel (2017a) described Navarana pearylandica Peel, 2017a, Liangshanella? nivalis Peel et al., 2016 and Zepaera? sp. stjernes $\varnothing$ Formation at Navarana Fjord (NF) and Løndal (Lø), in the Kap Troedsson Formation at Harder Gletscher $(\mathrm{HaG})$ and in the Buen Formation at Brillesø. c Stratigraphic schemes at Løndal in the western Peary Land and southern Lauge Koch Land area compared to northern Navarana Fjord, showing derivation of material: A, Aftenstjernes $\varnothing$ Formation assemblages at Navarana Fjord and Løndal; B, Buen Formation assemblage at Brilles $\varnothing$ in Peary Land

Elsewhere in Greenland, Poulsen (1932) noted Bradoria sp. from the Bastion Formation of North-East Greenland (Fig. 1a, inset map), while Skovsted (2006) described Albrunnicola sp., Liangshanella sayutinae (Melnikova, 1988) and Indiana secunda (Matthew, 1895) from the same area. Scale-bearing hollow spines of Mongolitubulus henrikseni Skovsted and Peel, 2001 from the Bastion Formation were shown to be part of the exoskeleton of a bradoriid by Skovsted (2005).

The present paper describes spinose bradoriids from the middle part of the Buen Formation and the lower member of the overlying Aftenstjernes $\varnothing$ Formation of North Greenland (Fig. 1c). The material is referred to two genera originally proposed in distant Cambrian palaeocontinents, and expands earlier reports of their occurrence in Laurentia. Spinospitella was described from the Mernmerna Formation (Cambrian Stage 4) of South Australia (Skovsted et al. 2006), where it appears to be widespread in the Dailyatia odyssei shelly fossil Zone (Betts et al. 2017). Spinospitella has also been reported from the Shackleton Limestone in the Transantarctic Mountains of Antarctica (Betts et al. 2017; Claybourn et al. 2019, 2020). The recent description of Spinospitella from small carbonaceous fossil assemblages in the Buen Formation (Wallet et al. 2020) is confirmed by a complete individual from the basal Aftenstjernes $\emptyset$ Formation at Navarana Fjord (Fig. 2). Its occurrence in North Greenland 


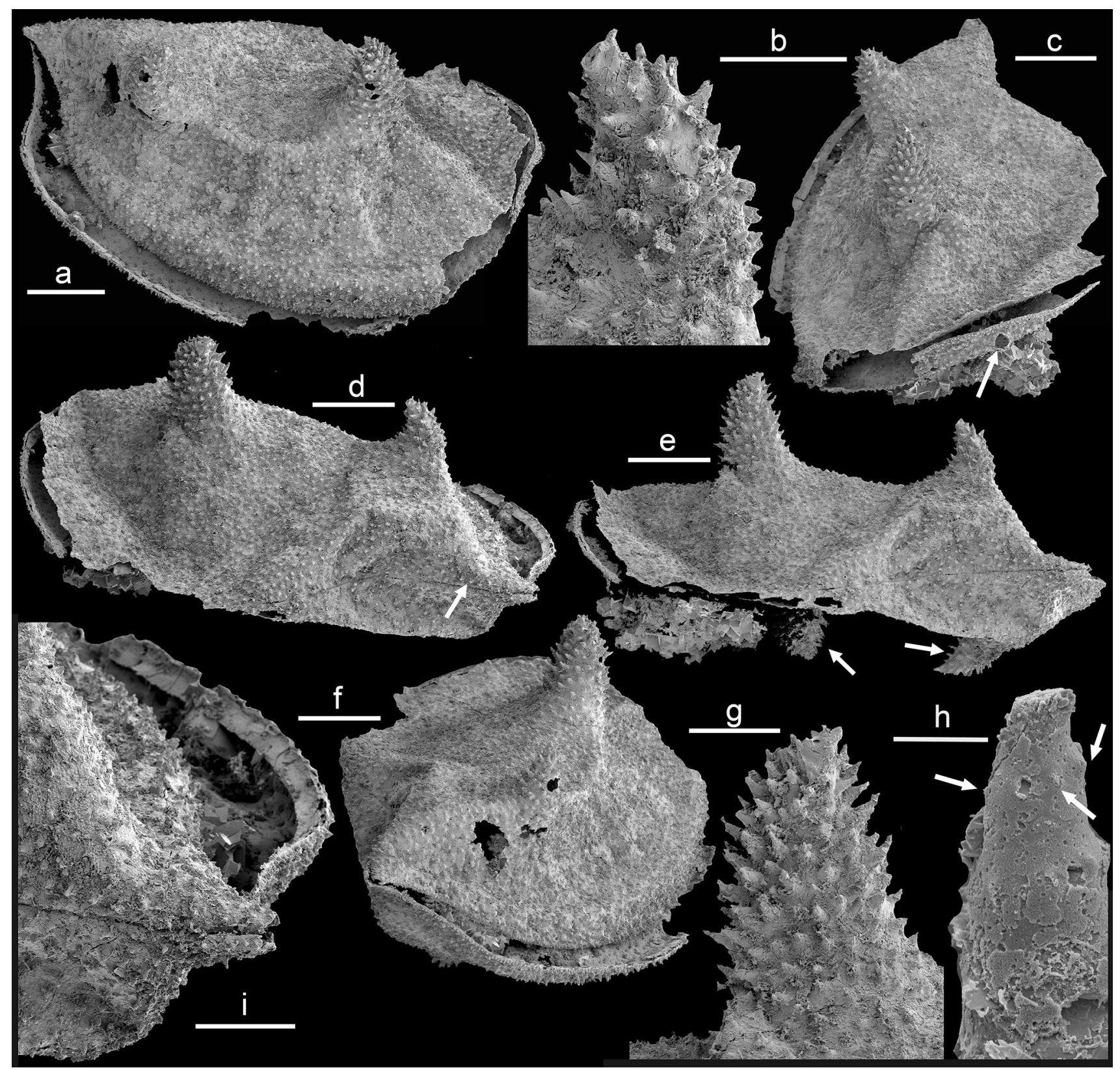

Fig. 2 Spinospitella coronata Skovsted et al., 2006, PMU 36980 from GGU sample 313012, Navarana Fjord, North Greenland, Aftenstjernes $\varnothing$ Formation, Cambrian Series 2, Stage 4; a left valve in lateral view; $\mathbf{b}$ anterior first order spine with covering of second order spines; c oblique posterior view with base of broken marginal spine (arrow); d dorso-lateral view showing hinge line (arrow), enlarged

adds to the similarity between East Gondwana (Australia and Antarctica) and Greenland Cambrian Stage 3-Stage 4 faunal assemblages of Small Shelly Fossils first noted by Skovsted (2006).

Nikolarites Vassiljeva (Vasilieva), 1994 is a poorly known genus based on fragmented specimens from the Pestrotsvet Formation, late Atdabanian Stage (Cambrian in $\mathbf{i}$, anterior to right; $\mathbf{e}$ dorsal view showing spines on right valve (arrowed), anterior to right; f oblique anterior view; $\mathbf{g}$ posterior first order spine with covering of second order spines; $\mathbf{h}$ second order spine with corona of third order spines (arrows). Scale bars $10 \mu \mathrm{m}$ (i), $200 \mu \mathrm{m}(\mathbf{b}, \mathbf{g}, \mathbf{h}), 500 \mu \mathrm{m}(\mathbf{a}, \mathbf{c}-\mathbf{f})$

Stage 3) in the Lena-Aldan region, Siberia (Vasilieva 1994, 1998). It was first reported as rare fragments from Greenland by Skovsted (2006) but the present abundant material adds support to its interpretation as a bradoriid, as suggested by Skovsted et al. (2006) and Kouchinsky et al. (2015). The current material clarifies the relationship between the two genera, focusing on their contrasting 
preservation and distribution in different environments in the lower Cambrian shelf succession of North Greenland.

\section{Geological background}

Cambrian sediments in North Greenland accumulated on the present day southern margin of the transarctic Franklinian Basin (Higgins et al. 1991; Ineson and Peel 1997), a site that lay across the equator during the Cambrian (Torsvik and Cocks 2016). A southern shelf area is bounded to the north of the present study area (Fig. 1a) by a deep-water trough succession, which subsequently became the focus of Ellesmerian deformation (Higgins et al. 1991). Deposition of the Buen Formation (Cambrian Stages 3-4; thickness $325-500 \mathrm{~m}$ in the southern area) followed a major regional transgression across a karstified earliest Cambrian platform, and commenced with a sandstone-dominated lower member (Bryant and Pickerill 1990; Ineson and Peel 1997; Peel and Willman 2018). A second marine advance introduced an upper member of dark, richly fossiliferous mudstones (Peel and Willman 2018; Slater et al. 2018; Wallet et al. 2020).

The overlying Brønlund Fjord Group (Cambrian Series 2-Miaolingian Series; Fig. 1c) is a carbonate-dominated complex that prograded across the shelf towards the northern deep-water trough (Higgins et al. 1991; Ineson and Peel 1997). In the southern J.P. Koch Fjord area, the Brønlund Fjord Group (Fig. 1c) consists of an alternation of cliff-forming formations made up of prograding cross-bedded dolomitic grainstones with conspicuous debris flows, deposited during sea level highstands, and recessive mudstone-carbonate units that represent lowstand conditions (Higgins et al. 1991; Ineson and Peel 1997). This lithostratigraphic subdivision is not applicable in northern J.P. Koch Fjord, where the prograding carbonate units have thinned out, and the succession is dominated by outer shelf mudstones and carbonates assigned to the Henson Gletscher and Kap Stanton formations (Ineson et al. 1994; Fig. 1c).

The Aftenstjernes $\emptyset$ Formation represents the first of these carbonate progradation events, overlying the siliciclastic shelf sediments of the Buen Formation (Ineson and Peel 1997; Peel and Willman 2018), and it can be traced north almost to the outer margin of the shelf. It is dominated by cliff-forming dolostone grainstones that attain a thickness of about $62 \mathrm{~m}$ (Ineson and Peel 1997) in its type area at the head of J.P. Koch Fjord (Fig. 1a, locality TS) but this value is reduced to only $18 \mathrm{~m}$ at the Navarana Fjord locality (Fig. 1a, locality NF). Fossils from the Aftenstjernes $\emptyset$ Formation are restricted generally to the basal member (usually 3-5 $\mathrm{m}$ in thickness) of dolomitic grainstones rich in glauconite, phosphorite bioclasts, pyrite and phosphatized hardgrounds, but limestones are present in Løndal (Frykman 1980; Peel 2017b). The lower member accumulated in a sediment-starved outer ramp setting and can be traced from southern to northern J.P. Koch Fjord, and in outcrops eastward to Løndal and across southern Peary Land, beyond.

\section{Materials and methods}

GGU sample 184004 was collected by J. S. Peel on 16 June 1974 from the lower part of the upper member of the Buen Formation at Brilles $\varnothing\left(82^{\circ} 13^{\prime} \mathrm{N}, 29^{\circ} 58^{\prime} \mathrm{W}\right)$ in southern Peary Land (Fig. 1b; Peel and Willman 2018).

GGU samples 255501, 255502 and 255503 were collected by P. Frykman on 11 July 1979 in Løndal, western Peary Land $\left(82^{\circ} 16^{\prime} \mathrm{N}, 37^{\circ} 03^{\prime} \mathrm{W}\right)$ from $10 \mathrm{~cm}, 50 \mathrm{~cm}$ and $90 \mathrm{~cm}$, respectively, above the lowest exposed level of the lower member of the Aftenstjernes $\varnothing$ Formation (Fig. 1a, locality L $\varnothing$ ). GGU sample 255513 was collected by P. Frykman on 12 July 1979 about 150 m north-east of GGU samples 255501-255503, about $1.35 \mathrm{~m}$ above the junction between the Buen Formation and the overlying lower member of the Aftenstjernes $\varnothing$ Formation.

GGU sample 313012 was collected by A.K. Higgins on 28 June 1984 from the lowest beds of the Aftenstjernes $\varnothing$ Formation on the southern limb of the prominent Navarana Fjord anticline in Sect. 12 of Higgins et al. (1992) at $82^{\circ} 35.5^{\prime} \mathrm{N}, 42^{\circ} 14^{\prime} \mathrm{W}$ (Fig. 1a, locality NF). In this section the Aftenstjernes $\varnothing$ Formation overlies dark mudstones of the Buen Formation and attains a thickness of $18 \mathrm{~m}$, culminating in a 3-4 $\mathrm{m}$ thick debris flow. Overlying strata were assigned to the Henson Gletscher Formation by Higgins et al. (1992).

Small Carbonaceous Fossils from mudstones of GGU sample 184004 were extracted using techniques described by Butterfield and Harvey (2012), and subsequently mounted for SEM study (Wallet et al. 2020). Other samples were limestones and dolostones that were digested in weak acetic acid following the protocol established by Jeppsson et al. (1985) prior to mounting of selected specimens from the residues for SEM study.

Abbreviations and repositories. GGU prefix-indicates a sample collected by Grønlands Geologiske Undersøgelse (Geological Survey of Greenland), now part of the Geological Survey of Denmark and Greenland (GEUS), Copenhagen, Denmark. PMU prefix-denotes a specimen deposited in the palaeontological type collection of the Museum of Evolution, Uppsala University, Sweden. 


\section{Environmental control}

The single, almost complete and only slightly deformed specimen of Spinospitella coronata was the only skeletal fragment recovered following acid digestion of a finegrained dark carbonate sample (weight about $0.5 \mathrm{~kg}$ ), interpreted as representing the ambient outer shelf environment and its autochthonous fauna from Navarana Fjord (Fig. 2). In contrast, several other samples from the Aftenstjernes $\varnothing$ Formation, at and adjacent to the same locality at Navarana Fjord (Fig. 1a, locality NF), contain a rich small shelly fauna, with 50 species documented by Peel (2020, 2021); these assemblages are clearly allochthonous and have been transported down slope with disarticulation, sorting and erosion as a consequence.

Sample residues from Løndal, to the south-east (Fig. 1a, locality Lø), are also rich in Small Shelly Fossils and many elements in the fauna occur also in the allochthonous assemblages from Navarana Fjord (Peel 2021). The Løndal samples show clear evidence of erosion, disarticulation and other taphonomic changes, and contain numerous fragments of Nikolarites (Figs. 4, 5) that are not present in the Aftenstjernes $\varnothing$ Formation samples from Navarana Fjord. Peel and Willman (2018: fig. 9H, I), however, illustrated robust spines, which they assigned to the bradoriid Petrianna? sp. from siltstones of the uppermost Buen Formation rich in comminuted transported shells at the same locality, immediately below the boundary with the overlying Aftenstjernes $\varnothing$ Formation at Navarana Fjord.

Wallet et al. (2020) compared the distribution of Spinospitella in residues of Small Carbonaceous Fossils from the Buen Formation from Brilles $\varnothing$ with that of Isoxys volucris Williams et al., 1996, which is extremely common in the slightly older macro fauna of the Sirius Passet Lagerstätte (Williams et al. 1996; Stein et al. 2009; Nielsen et al. 2017; Fig. 1a, locality SPL). The smooth-shelled Isoxys, although bivalved, is not a bradoriid but a stem-group arthropod (Legg and Vannier 2013) and has been interpreted as a pelagic hunter (Vannier and Chen 2000; Zhao et al. 2014). Entire specimens from Sirius Passet range in length from $5 \mathrm{~mm}$ to more than $20 \mathrm{~mm}$, excluding the long terminal spines. Wallet et al. (2020) suggested that certain small broken spines in the Small Carbonaceous Fossil assemblage from Brilles $\varnothing$ may be Isoxys, but Peel and Willman (2018) did not identify Isoxys or Spinospitella among macrofossils at that locality.

In discussing the Spinospitella specimens, Wallet et al. (2020) suggested that the absence of such spinose forms from the slightly older Sirius Passet Lagerstätte (Fig. 1a, SPL) might reflect environmental control in terms of oxygen or depth parameters of the distribution of bradoriids within the Buen Formation, with the epibenthic Spinospitella-like forms being restricted to the shelf environments. Wallet et al.
(2020) noted that Spinospitella and specimens of the much larger Petrianna fulmenata Siveter et al., 1996 were known only from outer shelf deposits of the Buen Formation in southern Peary Land (Peel and Willman 2020), whereas thin-walled pelagic species of the bivalved Isoxys Walcott, 1890 were common in the Sirius Passet Lagerstätte and elsewhere (Williams et al. 1996; Vannier and Chen 2000; Paterson et al. 2008; Stein et al. 2009; Nielsen et al. 2017).

Unlike the Buen Formation around Brillesø (Slater et al. 2018; Wallet et al. 2020), no Small Carbonaceous Fossils are known from the transitional Buen Formation at Sirius Passet due to high levels of regional metamorphism (Vidal and Peel 1993). In general, the Sirius Passet Lagerstätte is dominated by large arthropods and lobopods, some of which achieve sizes of $25 \mathrm{~cm}$ and $45 \mathrm{~cm}$, respectively (Stein et al. 2013; Vinther et al. 2016). Fossil specimens less than about $5 \mathrm{~mm}$ are generally absent, suggesting that the absence of the small specimens of Spinospitella, if initially present, may result from a taphonomic or diagenetic filter. As noted above, Spinospitella is well represented in the small organic fossil fraction at Brilles $\varnothing$, but not in the described macrofauna (Peel and Willman 2018).

While the evidence regarding comparison of Spinospitella and Isoxys is equivocal, the thesis of environmental control put forward by Wallet et al. (2020) is supported by the present material. Robust fragments of thick, multi-layered, shield and associated spines of Nikolarites spasskyi are common in the Aftenstjernes $\varnothing$ Formation in Løndal (Fig. 1a). The fragments are often rounded and exfoliated, indicating erosion and transport in a relatively high energy setting; large sections of shield are absent. In contrast, the single specimen of the thinner shelled Spinospitella coronata from the outer shelf setting, at Navarana Fjord to the north, is articulated, almost complete and well preserved; fragments of shields of Spinospitella or Nikolarites are not known from this or other samples from the Aftenstjernes $\varnothing$ Formation at Navarana Fjord. These other samples from the Aftenstjernes $\varnothing$ Formation (exclusive of GGU sample 313012 with the complete Spinospitella specimen) clearly preserve allochthonous fossil material transported down slope, whereas the described complete specimen of Spinospitella coronata, the only fossil specimen recovered from a sample lacking comminuted shell material, is interpreted as representing the ambient environment and autochthonous fauna of the outer shelf. Although not specifically studied, the distribution of Spinospitella in South Australia seems to follow a similar pattern. In South Australia, Spinospitella is most common in the Mernmerna Formation, representing a carbonate ramp-slope facies and is less common in the older Wilkawillina and Wirrapowie Limestones, which represent more shallow environments than the Mernmerna Formation (Betts et al. 2017). 
While the fragments of Spinospitella sp. from the Buen Formation are derived from geographically southern areas of North Greenland at Brilles $\varnothing$, they accumulated in mudstones at the deepest point of the major regional transgression in the middle Buen Formation prior to the upwards shallowing trend that continued up to the basal Aftenstjernes $\emptyset$ Formation (Ineson and Peel 1997). Environmentally, these outer shelf mudstones from the medial Buen Formation are akin to the outer shelf fine grained sediments at Navarana Fjord, and both yield Spinospitella. The robust shields of Nikolarites spasskyi in the Aftenstjernesø Formation from Løndal characterize higher energy inner shelf conditions than Spinospitella, which favoured a quieter, outer shelf environment.

Peel (2017a) described a different assemblage of bradoriids from the Kap Troedsson Formation near Harder Gletscher (Fig. 1b, HaG), stratigraphically continuous with the basal member of the Aftenstjernes $\varnothing$ Formation. Well preserved specimens of Beyrichona avannga Peel, 2017a and Hipponicharion skovstedi Peel 2017a occur in a shallow carbonate ramp succession (Ineson and Peel 1997), which lacks the robust ornamented spines of Nikolarites. Neither are Beyrichona avannga and Hipponicharion skovstedi known from the basal Aftenstjernes $\varnothing$ Formation, suggesting the differentiation of a third bradoriid community in addition to the Nikolarites and Spinospitella faunas from the inner to outer shelf.

\section{Systematic palaeontology}

\author{
Euarthropoda sensu Walossek, 1999 \\ Order Bradoriida Raymond, 1935 \\ Family uncertain
}

Discussion. Rozanov (1986: 89) suggested that a new family Mongolitubulidae might be erected within hyolithelminths to include Mongolitubulus, at that time considered to be tubular rather than spinose, but it was later discussed also as a "conodontomorph" by Rozanov and Zhuravlev (1992). Topper et al. (2013) proposed Mongolitubulidae as a new family of Bradoriida to include the eponymous genus, Tubuterium Melnikova, 2000, Spinospitella and possibly Rushtonites Hinz, 1987. However, it is apparent that Mongolitubulus, as currently recognised, is a form genus for similar ornamented spines (Skovsted and Peel 2001; Skovsted 2005). A variety of spinose shield morphologies is included in the genus, ranging from Mongolitubulus unispinosa Topper et al., 2007 to the multi-spined Mongolitubulus henrikseni Skovsted and Peel, 2001. The polyphyletic nature of spines referred to Mongolitubulus was discussed by $\mathrm{Li}$ et al., (2012) and Caron et al. (2013) who noted that material from Greenland assigned to Mongolitubulus squamifer
Missarzhevsly 1977 by Skovsted and Peel (2001) could be interpreted as the spines of a hallucigeniid lobopodian. The lobopodian hypothesis concerning Mongolitubulus was earlier put forward by Dzik (2003) on the basis of specimens from the early Cambrian Shabatky Formation of Khazakhstan. Taxonomically, the issue is confused, since material described by Meshkova (1985), Skovsted and Peel (2001), Dzik (2003) and Wrona (2004, 2009), and discussed by Caron et al. (2013), is referred by these authors to the type species, Mongolitubulus squamifer Missarzhevsky, 1977 from Mongolia. While other species referred to Mongolitubulus by Skovsted and Peel (2001), Skovsted (2005), Skovsted et al. (2006), Topper et al. (2007), Kouchinsky et al. (2015) are demonstrably bradoriids, the status of Missarzhevsky's (1977) type material from Mongolia remains equivocal, as is that of the family.

McMenamin (2020) did not discuss Mongolitubulidae, but assigned Mongolitubulus, Nikolarites (as Nicolarites) and Spinospitella to the Family Duibianellidae Shu, 1990, together with Duibianella Shu, 1990 (inadvertently spelt Dubianella), Neoduibianella Shu, 1990, Spinella, Zhang 2007 (which he considered to be a synonym of Mongolitubulus unispinosa Topper et al., 2007) and Kazakhstanotubulus Gridina, 1991. Topper et al. (2013: 73) commented that spines of Duibianella differ from those of Mongolitubulus and Spinospitella by being ornamented with lower nodes rather than elongated spines, but they are compared here to Nikolarites.

At this time, Mongolitubulus and Spinospitella are left unassigned at family level, while Nikolarites is assigned tentatively to Duibianellidae.

Genus Spinospitella Skovsted et al., 2006

Type species. Spinospitella coronata Skovsted et al., 2006 from the Mernmerna Formation of South Australia, Cambrian Series 2, Stage 4.

Discussion. Skovsted et al. (2006) described Spinospitella from the Mernmerna Formation (Cambrian Stage 3-4) of South Australia based on collections containing a juvenile valve and partially broken bradoriid shields showing exquisite details of the ornamentation.

The distinctive ornamentation of a fine net draped around spines and tubercles characteristic of Spinospitella to form a honeycomb pattern has been described also in Nikolarites spasskyi Vassiljeva [Vasilieva], 1994 from the Atdabanian of the Lena-Aldan region of Yakutia, Siberia (Vasilieva 1994), and in bradoriids such as Duibianella and Neoduibianella superbly illustrated by Zhang (2007) from the Cambrian of China. While the fragmentary nature of the Siberian specimens (Vasilieva [Vassiljeva 1998]: pls. 39, 40) inhibits unequivocal interpretation, they represent almost certainly fragments of a bradoriid that can be differentiated from 
Spinospitella in terms of the micro-ornamentation of the shield.

In contrast to Spinospitella, Skovsted et al. (2006: 14) noted that the network pattern in the ornamentation continued over the summit of second order spines and tubercles in Nikolarites, a feature visible in some of the illustrations in Vasilieva $(1994,1998)$ and Kouchinsky et al. (2015). This observation is confirmed here in material from North
Greenland and provides a more solid base for the recognition of Nikolarites. It is stressed, however, that gross features of the shield of Nikolarites are not known. Future study may determine that shields with dissimilar gross morphology may simply share similar ornamentation, a situation reminiscent of that in Mongolitubulus, where several species are recognised, mainly on the nature of the prominent spines. Given the interpreted defensive function of the

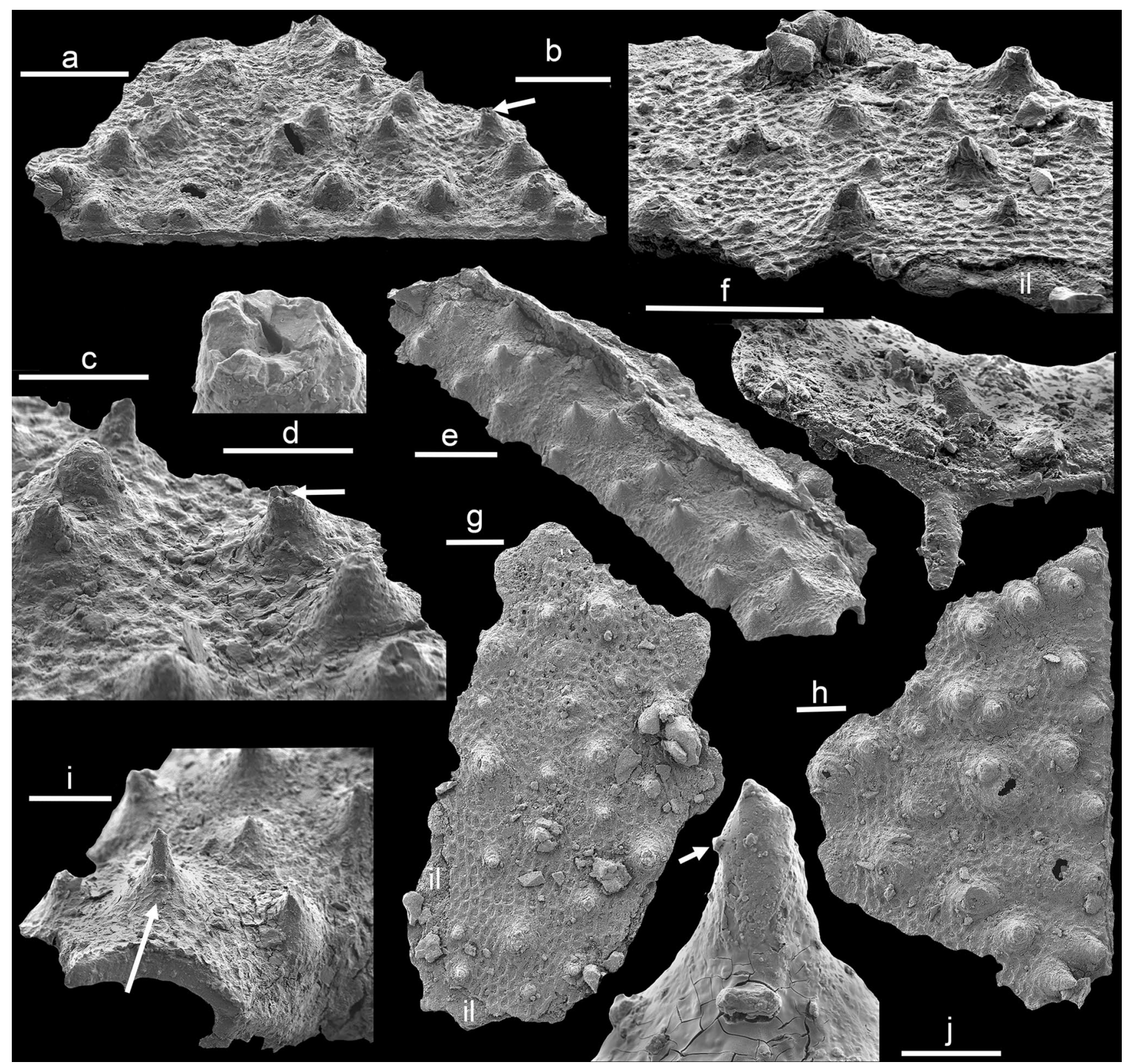

Fig. 3 Small Carbonaceous Fossils of Spinospitella cf. coronata from GGU sample 184004, Brilles $\varnothing$, southern Peary Land, North Greenland, Buen Formation, Cambrian Series 2, Stage 4; a, c, d, h PMU 36,304 , preserving a straight margin $(\mathbf{c}, \mathbf{h})$, arrow points to broken hollow spine enlarged in $\mathbf{c}$ and $\mathbf{d} ; \mathbf{e}, \mathbf{i}, \mathbf{j}$ PMU 36,303, showing gentle curvature, lower-right termination enlarged (i) to show detail of orna- mentation of second-order spines; arrow points to spine enlarged in $\mathbf{j}$; $\mathbf{j}$ detail of spine showing incomplete corona of third-order spines (arrow); f PMU 36,306 showing rounded margin bearing a spine; b, g PMU 36,305, showing inner layer (il) overlain by ornamented outer layer enlarged in $\mathbf{b}$. Scale bars $5 \mu \mathrm{m}(\mathbf{j}), 10 \mu \mathrm{m}(\mathbf{d}), 50 \mu \mathrm{m}(\mathbf{b}, \mathbf{c}, \mathbf{f}-\mathbf{i})$ and $100 \mu \mathrm{m}(\mathbf{a}, \mathbf{e})$ 
Mongolitubulus spines (Skovsted and Peel 2001), it is not unlikely that similar structures were developed on otherwise dissimilar shields.

Amphikeropsis myklosis Topper et al., 2007 from the Mernmerna Formation of South Australia (Topper et al. 2007: figs. 7D-K, 8) resembles Spinospitella in terms of the two prominent spines on each shield, but lacks the hollow second order spines. Topper et al. (2007) suggested that A. myklosis may have belonged to the same group of bradoriids as Spinospitella, Duibianella and Mongolitubulus, and by inference Nikolarites, but this hypothesis is presently difficult to test.

Spinospitella coronata Skovsted et al., 2006

Figures 2, 3

2006 Spinospitella coronata Skovsted, Brock and Paterson: 21, figs. 6-9.

2007 Spinospitella coronata-Topper, Skovsted, Brock and Paterson: 85, fig. 9.

2011 Spinospitella coronata-Topper, Skovsted, Brock and Paterson: fig. $7 \mathrm{~N}$.

2016 Spinospitella coronata-Betts, Paterson, Jago, Jacquet, Skovsted, Topper and Brock, fig. 20L-P.

2018 bradoriid fragments (cf. Spinospitella) - Slater et al.: fig. 2Q-AI.

2020 Spinospitella coronata-McMenamin: 24.

2021 (bradoriids)—Wallet et al.: fig. 4.

Material. PMU 36,980 from GGU sample 313012, eastern side of Navarana Fjord, Lauge Koch Land, North Greenland (Fig. 1a, locality NF); lower Aftenstjernes $\emptyset$ Formation. PMU 36,303-PMU 36,306 from GGU sample 184004, middle Buen Formation, Brillesø, Peary Land (Fig. 1b). All specimens from Cambrian Series 2, Stage 4.

Occurrence. Mernmerna Formation (Skovsted et al. 2006; Topper et al. 2007; Betts et al. 2017), of South Australia; Cambrian Series 2, Stages 3-4. Buen Formation and Aftenstjernes $\varnothing$ Formation of North Greenland; Cambrian Series 2, Stage 4. Spinospitella sp. was reported from the Holyoake Formation of East Antarctica (Claybourn et al. 2019; Claybourn 2020); Cambrian Series 2, Stage 4. Rare specimens were also reported from the older Wilkawillina Limestone and Wirrapowie Limestone (Betts et al. 2016) of South Australia; Cambrian Series 1, Stage 2, but these occurrences need to be confirmed by further studies.

Description. Equivalved bradoriid arthropod, postplete in large specimens but almost bilaterally symmetrical in juveniles. Hinge line gently convex in lateral view, marked by a narrow groove (Fig. 2d, arrow). Antero-cardinal angle produced into a short but distinct spine (Fig. 2a); posterocardinal termination seemingly angular. Ventral margin in lateral view initially concave below the antero-cardinal spine, but thereafter uniformly convex (Fig. 2a). Ventral margin of right valve (left not visible for comparison) with acute transition from spinose outer surface to a smooth inward sloping rim on the interior (Fig. 2d, i). Outer margin of shield flattened with a narrow brim in juvenile (Skovsted et al. 2006: fig. 9D) but inflated to form a broad, convex, comarginal ramp in adult, widest posteriorly (Fig. 2a). Each valve in the adult ornamented by two prominent, robust, first order spines located at one third of the distance from the hinge to the ventral margin; posteriormost spine is larger (Fig. 2e, spines arrowed on right valve). Anterior spine located at about one quarter of the length; broadly based, tapering, and curved towards the posterior (Fig. 2a, d, e). Posterior spine located at about two thirds of valve length, with its tip curved anteriorly (Fig. 2e, g). Shape of inner valve area seemingly with a broad comarginal ridge connecting the two first order spines and with three obscure radial folds in the posterior half of the shell connecting this to the marginal ramp (Fig. 2a).

External shield surface, including the first order spines, covered by closely spaced, pointed, second order spines; the intervening polygonal network obscured by encrustation. Second order spines slender, smooth, but with circlets of short, stubby, third order spines (Fig. 2h). Internal surface of the shield with circular pits corresponding to the hollow second order spines. A broken spine base indicates a large spine close to the posterior margin of the right valve, absent from the left valve (Fig. 2c, arrow).

Discussion. Spinospitella coronata was fully described by Skovsted et al. (2006) whose description placed particular emphasis on the nature of the spinose ornamentation. A circlet of third order spines was considered a diagnostic character for Spinospitella coronata by Skovsted et al. (2006). These fine structures are not always present in specimens from Australia (Skovsted et al. 2006; Topper et al. 2007; Betts et al. 2016, 2017), presumably due to preservational factors such as abrasion and/or coating by secondary minerals. However, we note that the best preserved specimens in the type lot are juveniles (see discussion below) and until more complete and well preserved larger specimens are known from Australia the taxonomic implications of presence/absence of the third order spines will remain uncertain. Fine details of the outer surface sculpture are partly obscured in the Navarana Fjord specimen by a thin, crystalline or flaky, diagenetic coating, presumably of phosphate, although poorly preserved circlets of third order spines (Fig. $2 \mathrm{~h}$, arrows) can be recognized on the second order spines that cover the shield surface. A similar spine is preserved on a carbonaceous fragment from Brilles $\varnothing$ (Fig. 3i, j, arrows). 
The single specimen from Navarana Fjord is a slightly crushed, almost complete individual $3.4 \mathrm{~mm}$ long (Fig. 2a), with height about half of length. It is twice the height of the holotype (Skovsted et al. 2006: fig. 9A), whereas the largest specimen figured by Topper et al. (2007) had a length of $2.1 \mathrm{~mm}$. Thus, the Navarana Fjord specimen is the largest specimen of Spinospitella coronata so far described and the great size difference between this and the complete juvenile, length $750 \mu \mathrm{m}$, figured by Skovsted et al. (2006: fig. 9D-F), together with specimens from the Buen Formation (Wallet et al. 2020), is reflected in morphological changes during ontogeny. The most notable ontogenetic changes include the enhanced postplete shape and greater prominence of the antero-dorsal spine. The relief of the first order spines is also increased in the adult and their tips turn in towards each other. Second order spines are more strongly developed and acute, reflecting an ontogenetic trend observed by Skovsted et al. (2006).

Fragments from the middle Buen Formation tentatively assigned to Spinospitella coronata more clearly show the network between the second order spines. The latter preserve third order spines (Fig. 3j) and often appear to be perforated (Fig. 3d, arrow). However, this reflects corrosion of the thin walls at their tips so as to penetrate the outer ornamented layer (Fig. 3b). One fragment displays a marginal spine (Fig. 3f) that can be compared to the broken marginal spine in the specimen from Navarana Fjord (Fig. 2c, arrow).

? Family Duibianellidae Shu, 1990

Genus Nikolarites Vassiljeva [Vasilieva, 1994]

Type species. Nikolarites spasskyi Vassiljeva [Vasilieva], 1994, Pestrotsvet Formation, late Atdabanian Stage (Cambrian Stage 3), Lena-Aldan region, Siberia.

Diagnosis. Seemingly a bradoriid with two or more large, hollow, first order spines of variable form on each shield; their placement unknown. Shield surface covered by closely spaced, conical tubercles about $50 \mu \mathrm{m}$ in diameter with a distinct apical node. Tubercles varying in shape and inclination from conical to inclined, becoming spinose on the first order spines (Fig. 5a, e, k). Outer surface ornamented by a raised network of four to six sided cells which drapes over the tubercles, rising up their sides (Fig. 4k); inner surface smooth, with depressions corresponding to the hollow inner surface of the tubercles on the outer surface (Fig. 4e). Shield composed of several laminated layers, with the spines notably robust.

Discussion. In the literature, the genus is variously referred to as Nikolarites or Nicolarites, combined with the specific epithet spasskyi or spasskii, and its author as Vassiljeva, Vasilieva or Vasil'eva (1994). In the original publication (1994), the author of the paper is transliterated as Vasilieva, N.I., but the taxon itself is described as Nikolarites spasskyi Vassiljeva. In 1998, Vasilieva is stated to be the author of the publication, but the taxon is referred to Nikolarites spasskii Vasil'eva (1994), 1998: 113).

Vasilieva $(1994,1998)$ assigned Nikolarites to the cambroclave Family Zhijinitidae Qian, 1978 but there is little similarity in form and structure to cambroclavids as described by Conway Morris and Menge (1991). Comparison of the fragments from North Greenland with material illustrated from the Pestrotsvet Formation of Yakutia by Vasilieva $(1994,1998)$ and from the Emyaksin Formation of the Anabar uplift by Kouchinsky et al. (2015) leaves little doubt that Nikolarites is a bradoriid.

Nikolarites differs from Spinospitella in terms of the ridges of the honeycomb pattern network extending onto the lower sides (Fig. 4i, k) of the tubercles (equivalent to the secondary spines of Spinospitella). The upper parts of tubercles are often smooth, in part due to exfoliation (Fig. 4a). The tubercles (Fig. 4f, i, k, l) and even the large spines (Fig. 5b, g) of Nikolarites also terminate in a swollen, smooth node not seen in Spinospitella, whereas second order spines of Spinospitella carry circlets of small third order spines (Figs. 2h, 3j) absent in Nikolarites.

Capricambria Hinz, 1991 from the Miaolingian Series (late Wuliuan Stage) of Queensland has a pair of prominent spines on each shield. The surface of the shields is covered by a raised network of ridges, but the abundant small tubercles of Nikolarites are lacking.

The terminal nodes on tubercles of Nikolarites invite comparison with Duibianella from the Yu' anshan Formation (late Cambrian Stage 3) in China, but the shields of the latter are covered with numerous, large and closely packed, globose nodes, some of which carry circlets of minor nodes or spines and the inflated termination (Zhang 2007: pl. 8, figs. 11-15). Neoduibianella from the Shuijingtuo Formation (late Cambrian Stage 3) has three or four, widely spaced, large, globose, first order spines covered with small tubercles (Zhang 2007: pl. 9, figs. 7-12) that may be compared to the first order spines of Spinospitella and Nikolarites. Intervening shield areas of Neoduibianella are covered by a honeycomb pattern raised network similar to that seen in both Spinospitella and Nikolarites, but small tubercles of varying size are unequally scattered across the shield surface. These small tubercles often carry a swollen apical node as in Nikolarites (Zhang 2007: pl. 9, fig. 7). Nikolarites differs from Neoduibianella in possessing long, slender first order spines (Fig. 5a, b) compared to the barrel-shaped spines of the latter genus, and more abundant tuberculation of the shields. Overall similarities suggest, however, that Nikolarites and Neoduibianella are closely related. 


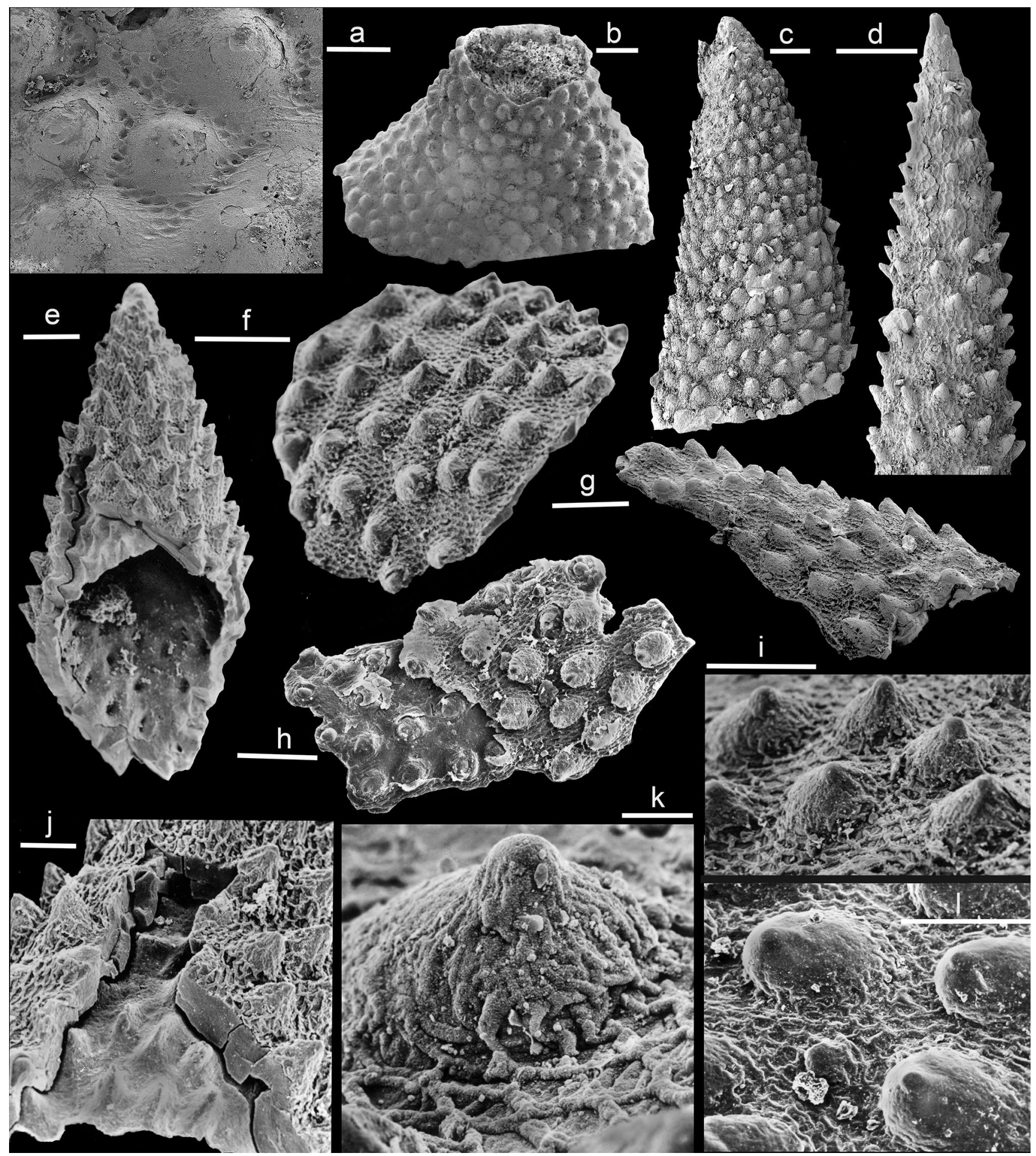

Fig. 4 Nikolarites spasskyi Vassiljeva, 1994, Aftenstjernes $\emptyset$ Formation, North Greenland, Cambrian Stage 4. All samples from Løndal, Peary Land, North Greenland. a, b PMU 38,139 from GGU sample 255503, expanded base of major spine with detail of exfoliated surface (a); c PMU 38,140 from GGU sample 255503; d PMU 38,141 from GGU sample 255503; e, j PMU 38,142 from GGU sample 255502 broken spine showing layered, thick, shield with conical depressions on interior producing spines on the upper surface of the inner layer (j); f, i, k PMU 38,143 from GGU sample 255502, shield fragment showing conical tubercles with apical nodes and detail of honeycomb network on sides of tubercle (k); g PMU 38,144 from GGU sample 255502; h PMU 38,145 from GGU sample 255501, shield fragment with outer layer with honeycomb network (right) partly exfoliated (left); I PMU 38,146 from GGU sample 255513, detail of asymmetric tubercles with apical nodes set in honeycomb network. Scale bars $10 \mu \mathrm{m}(\mathbf{k}), 50 \mu \mathrm{m}(\mathbf{a}, \mathbf{i}, \mathbf{j}, \mathbf{l}), 100 \mu \mathrm{m}(\mathbf{c}-\mathbf{h})$, $200 \mu \mathrm{m}(\mathbf{b})$ 


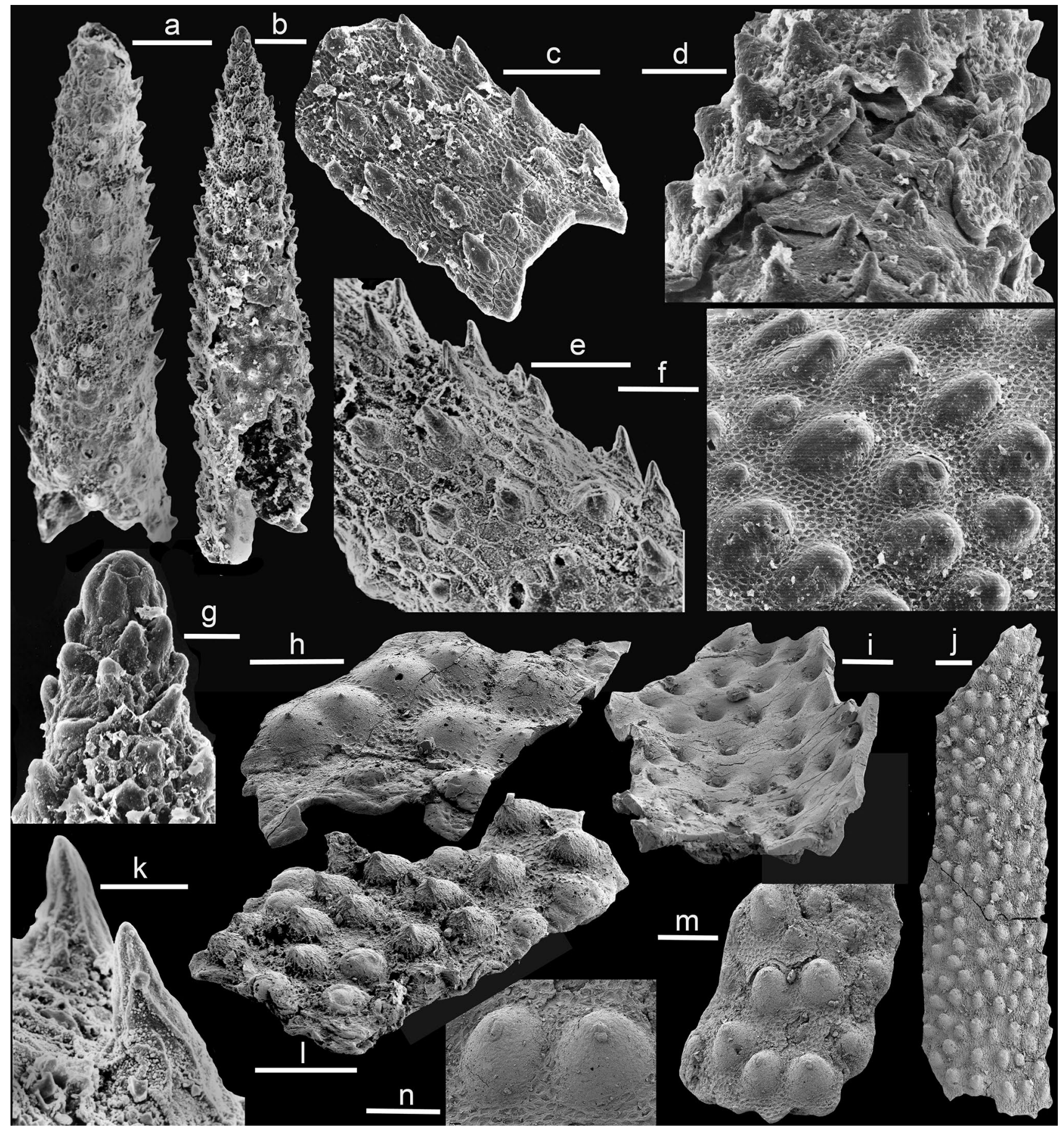

Fig. 5 Nikolarites spasskyi Vassiljeva, 1994, Aftenstjernes $\varnothing$ Formation, North Greenland, Cambrian Stage 4. All samples from Løndal, Peary Land, North Greenland. a, e, k PMU 38147 from GGU sample 255513, broken first order spine with detail of second order spines (e, k); b, d, g PMU 38,148 from GGU sample 255501, first order spine showing partially exfoliated outer layer (d) and rounded tip (g); c PMU 38,149 from GGU sample 255501, curved fragment showing inclined tubercles; f PMU 38,150 from GGU sample 255502, detail of outer surface showing rounded, inclined, tubercles; $\mathbf{h}$ PMU 38,151 from GGU sample 255502, corroded and partially exfoliated fragment; i PMU 38,152 from GGU sample 255502, inner surface showing conical depressions; j PMU 38,153 from GGU sample 255502; I PMU 38,154 from GGU sample 255502; m, n PMU 38,155 from GGU sample 255502, fragment showing detail of honeycomb network exfoliated from rounded tubercles, detail in (n). Scale bars $20 \mu \mathrm{m}(\mathbf{g}, \mathbf{k}), 50 \mu \mathrm{m}(\mathbf{d}, \mathbf{e}, \mathbf{i}, \mathbf{n}), 100 \mu \mathrm{m}(\mathbf{a}-\mathbf{c}, \mathbf{f}, \mathbf{h}, \mathbf{j}, \mathbf{l}, \mathbf{m})$ 
Nikolarites spasskyi Vassiljeva [Vasilieva], 1994

Figures 4, 5

1994 Nikolarites spasskyi Vassiljeva [Vasilieva]: 7, pl. 2, fig. 1.

1998 Nikolarites spasskii Vassiljeva-Vasilieva: 113, pl. 39, figs. 1-6; pl. 40, figs. 1-5.

2001 Nicolarites spasskyi-Skovsted and Peel: 146.

2006 Nicolarites spasskyi-Skovsted: 1104, fig. 10.20, 10.21

2020 Nicolarites—McMenamin: 21.

Material. PMU 38,139, PMU 38,140, PMU 38,141 from GGU sample 255503; PMU 38,142, PMU 38,143, PMU 38,144, PMU 38,150, PMU 38,151, PMU 38,152, PMU 38,153, PMU 38,154, PMU 38,155 from GGU sample 255502; PMU 38,145, PMU 38,148, PMU 38,149 from GGU sample 255501; PMU 38,146, PMU 38,147 from GGU sample 255513. All samples from the Aftenstjernes $\varnothing$ Formation, Cambrian Stage 4. Løndal, Peary Land, North Greenland.

Occurrence. Pestrotsvet Formation (Vasilieva 1994, 1998), late Atdabanian Stage (Cambrian Stage 3), Lena-Aldan region, Siberia. Bastion Formation (Cambrian Stage 4), North-East Greenland (Skovsted 2006). Aftenstjernes $\varnothing$ Formation (Cambrian Stage 4), North Greenland.

Discussion. The gross morphology of the shields, including the number and distribution of large spines, is not known. The holotype figured by Vasilieva $(1994,1998)$ is a triangular fragment of a shield, $1.5 \mathrm{~mm}$ long but broken on all sides, bearing two prominent spines joined by a low swelling. The larger spine has been broken away from its raised base but reveals its circular cross section. The smaller spine has a low conical shape and pointed apex. No equivalent fragment is known in the current material from North Greenland, but a single large fragment from North Greenland (Fig. 4b, length $2 \mathrm{~mm}$ ) preserves the conical base of a large circular spine about $700 \mu \mathrm{m}$ in diameter. The surface of the fragment and of the low conical spine is covered with a honeycomb pattern, a network of approximately 6-sided cells with sharply raised cords and depressed centres (Vasilieva 1998: pl. 39, fig. 4).

Conical tubercles with convex sides occur within the honeycomb pattern (Fig. 4f); individual tubercles are variable in width relative to height and culminate in an apical node (Fig. 4f, $\mathrm{i}, \mathrm{k})$. Interspaces between tubercles vary from one to two diameters of the tubercles, which is the area occupied by about three or four of the cells of the network (Vasilieva 1998: pl. 39, fig. 4). The tuberculate surfaces in Vasilieva's (1998) illustration appear identical to the pattern on gently curved fragments from North Greenland (Fig. 4f), where variation in spacing of the tubercles is more apparent. In pristine specimens (Fig. 4k), the ridges from the network rise towards the apex of the tubercles and the apical node is rounded. However, the ridges on the tubercles may be obscure or missing, often as a result of exfoliation or possibly corosion of the outer shield surface (Fig. 5m), although the apical node remains distinct (Fig. 5h, n). Individual tubercles may be radially symmetrical (Fig. 4f, i, k) or with their axis inclined (Figs. 4g, 1, 5f), the latter usually parallel to the axis of curvature of the fragments (Fig. 5c,j).

Vasilieva (1998: pl. 40) illustrated a slightly curved fragment of a slowly tapering spine (length about $1 \mathrm{~mm}$ ), circular in cross section but broken at each extremity. While the surface network is clearly expressed, the tubercles are pointed, thorn-like, slightly taller than wide, and widely spaced, with six or more cells between each spine. The apices of the thorn-like tubercles are directed distally from the broken base of the spine, and inclined at about 45 degrees to its surface; their sides are ornamented with irregular ridges. Closely similar spines from North Greenland vary from almost cylindrical with increased tapering towards the more uniformly tapering apex (Fig. 5b), to more uniformly narrow cones (Figs. 4d, 5a). While the honeycomb network may be somewhat coarser than in the specimen illustrated by Vasilieva ( 1998), the tubercles on the spines show similar shape, inclination and ornamentation (Fig. 5a, e, k), becoming narrower and more acute as the apex is approached. Where preserved, the apex of the spines is formed by a globose node (Fig. 5b, g). One illustrated spine (Fig. 4c) is a wider, slightly curved cone, with closely spaced inclined tubercles more similar in shape to the equidimensional tubercles of the shallowly convex fragments (Figs. 4g, 5l). Its form and curvature suggest that it may represent the type of spine attached to the large spine base (Fig. 4b). Vasilieva (1994) commented that the shield had three shell layers, and several layers are clearly seen in the robust Greenland material (Figs. 4e, j; 5d).

Skovsted (2006) assigned to Nikolarites two thick-shelled, cone-shaped, fragments with densely spaced tubercles from the Bastion Formation of North-East Greenland (Fig. 1c) that compare well with the robust base of a spine from North Greenland (Fig. 4b). A similar blunt spine was described as "Nodose cap" by Landing et al. (2002: 302, fig. 4.12) from the latest Early Cambrian "Anse Maranda Formation" of Ville Guay, Québec.

Acknowledgements Samples collected during the North Greenland Project (1978-80; 1983-4) of the Geological Survey of Greenland were kindly made available for study by Peter Frykman and the late Tony Higgins (Copenhagen). Marissa Betts (Armidale), David J. Siveter (Leicester) and editor Mike Reich (Munich) are thanked for comments concerning the manuscript. 
Funding Open access funding provided by Uppsala University.

Open Access This article is licensed under a Creative Commons Attribution 4.0 International License, which permits use, sharing, adaptation, distribution and reproduction in any medium or format, as long as you give appropriate credit to the original author(s) and the source, provide a link to the Creative Commons licence, and indicate if changes were made. The images or other third party material in this article are included in the article's Creative Commons licence, unless indicated otherwise in a credit line to the material. If material is not included in the article's Creative Commons licence and your intended use is not permitted by statutory regulation or exceeds the permitted use, you will need to obtain permission directly from the copyright holder. To view a copy of this licence, visit http://creativecommons.org/licenses/by/4.0/.

\section{References}

Betts, M.J., J.R. Paterson, J.B. Jago, S.M. Jacquet, C.B. Skovsted, T.P. Topper, and G.A. Brock. 2016. A new lower Cambrian shelly fossil biostratigraphy for South Australia. Gondwana Research 36: 176-208.

Betts, M.J., J.R. Paterson, J.B. Jago, S.M. Jacquet, C.B. Skovsted, T.P. Topper, and G.A. Brock. 2017. Global correlation of the early Cambrian of South Australia: Shelly fauna of the Dailyatia odyssei Zone. Gondwana Research 46: 240-279.

Briggs, D.E.G., D.H. Erwin, and F.J. Collier. 1994. The fossils of the Burgess Shale, 1-238. Washington, D.C.: Smithsonian Institution.

Bryant, I.D., and R.K. Pickerill. 1990. Lower Cambrian trace fossils from the Buen Formation of central North Greenland: Preliminary observations. Rapport Grønlands Geologiske Undersøgelse 147: 44-62.

Butterfield, N.J., and T.H.P. Harvey. 2012. Small carbonaceous fossils (SCFs): a new measure of early Paleozoic paleobiology. Geology 40: 71-74

Caron, J.-B., M.R. Smith, and T, H.P. Harvey. 2013. Beyond the Burgess Shale: Cambrian microfossils track the rise and fall of hallucigeniid lobopodians. Proceedings of the Royal Society (B: Biological Sciences) 280: 20131613. https://doi.org/10.1098/rspb. 2013.1613.

Claybourn, T.M. 2020. Biostratigraphy and sytematics of Cambrian small shelly fossils from East Antarctica and South Australia. Digital Comprehensive Summaries of Uppsala Dissertations from the Faculty of Science and Technology 1907: 1-63.

Claybourn, T.M., S.M. Jacquet, C.B. Skovsted, T.P. Topper, L.E. Holmer, and G.A. Brock. 2019. Mollusks from the upper Shackleton Limestone (Cambrian Series 2), Central Transantarctic Mountains, East Antarctica. Journal of Paleontology 93: 437-459.

Conway Morris, S., and C. Menge. 1991. Cambroclaves and paracarinachitids, early skeletal Problematica from the lower Cambrian of south China. Palaeontology 34: 357-397.

Dzik, J. 2003. Early Cambrian lobopodian sclerites and associated fossils from Kazakhstan. Palaeontology 46: 93-112.

Frykman, P. 1980. A sedimentological investigation of the carbonates at the base of the Brønlund Fjord Group (Early-Middle Cambrian) Peary Land, Eastern North Greenland: Rapport Grønlands. Geologiske Undersøgelse 99: 51-55.

Gridina, N.M. 1991. Ostatki konodontov i fosfatnykh problematiki v otlozheniyakh nizhnego kembriya centralnogo Kazakhstana. Paleontologicheskiy Zhurnal 1991: 102-108.

Higgins, A.K., J.R. Ineson, J.S. Peel, F. Surlyk, and M. Sønderholm. 1991. Lower Palaeozoic Franklinian Basin of North Greenland. Bulletin Grønlands Geologiske Undersøgelse 160: 71-139.
Higgins, A.K., N.J. Soper, and N.C. Davis. 1992. Lower Palaeozoic outer shelf and slope lithostratigraphy, Franklinian basin, North Greenland. Open File Series Grønlands Geologiske Undersøgelse 92(8): $1-57$.

Hinz, I. 1987. The Lower Cambrian microfauna of Comley and Rushton, Shropshire/England. Palaeontographica Abteilung (A: Paläozoologie, Stratigraphie) 198: 41-100.

Hou, X., D.J. Siveter, M. Williams, and X. Feng. 2002. A monograph of the bradoriid arthropods from the Lower Cambrian of SW China. Transactions of the Royal Society of Edinburgh, Earth Sciences 92: 347-409.

Hou, X., M. Williams, D.J. Siveter, D.J. Siveter, R.J. Aldridge, and R.S. Sansom. 2010. Soft-part anatomy of the Early Cambrian bivalved arthropods Kunyangella and Kunmingella: significance for the phylogenetic relationships of Bradoriida. Proceedings of the Royal Society London (B: Biological Sciences) 277: 1835-1841.

Hou, X., D.J. Siveter, D.J. Siveter, R.J. Aldridge, P. Cong, S.E. Gabbott, X. Ma, M.A. Purnell, and M. Williams. 2017. The Cambrian fossils of Chengjiang, China: The flowering of early animal life, 2nd ed., 1-316. Oxford: Wiley.

Ineson, J.R., and J.S. Peel. 1997. Cambrian shelf stratigraphy of North Greenland. Geology of Greenland Survey Bulletin 173: 1-120.

Ineson, J.R., and J.S. Peel. 2011. Geological and depositional setting of the Sirius Passet Lagerstätte (early Cambrian), North Greenland. Canadian Journal of Earth Sciences 48: 1259-1281.

Ineson, J.R., F. Surlyk, A.K. Higgins, and J.S. Peel. 1994. Slope apron and deep shelf sediments of the Brønlund Fjord and Tavsens Iskappe Groups (Lower Cambrian-Lower Ordovician), North Greenland: Stratigraphy, facies and depositional setting. Grønlands Geologiske Unders $\phi g e l s e$ Bulletin 169: 7-24.

Jeppsson, L., D. Fredholm, and B. Mattiasson. 1985. Acetic acid and phosphatic fossils-a warning. Journal of Paleontology 59: 952-956.

Kouchinsky, A., S. Bengtson, C. Clausen, and M. Vendrasco. 2015. An early Cambrian fauna of skeletal fossils from the Emyaksin Formation, northern Siberia. Acta Palaeontographica Polonica 60: 421-512.

Landing, E., G. Geyer, and K.E. Bartowski. 2002. Latest Early Cambrian small shelly fossils, trilobites, and Hatch Hill dysaerobic interval on the Québec continental slope. Journal of Paleontology 76: 287-305.

Legg, D.A., and J. Vannier. 2013. The affinities of the cosmopolitan arthropod Isoxys and its implications for the origin of arthropods. Lethaia 46: 540-550.

Li, G.X., M. Steiner, M.Y. Zhu, and X. Zhao. 2012. Early Cambrian eodiscoid trilobite Hupeidiscus orientalis from South China: Ontogeny and implications for affinities of Mongolitubulus-like sclerites. Bulletin of Geosciences 87: 159-169.

Matthew, G.F. 1895. The Protolenus fauna. Transactions of the New York Academy of Sciences 14: 101-153.

Matthew, G.F. 1902. Ostracoda of the basal Cambrian rocks in Cape Breton. Canadian Record of Science 8: 437-468.

McMenamin, M.A.S. 2020. Bradoriids (Arthropoda) and the Cambrian diversification. Geosciences 10(4): 119. https://doi.org/10.3390/ geosciences 10040119.

Melnikova, L.M. 1988. Nekotoryye bradoriidy (Crustacea) iz botomskogo yarusa vostochnogo Zabaykal'ya. Paleontologicheskiy Zhurnal 1988: 114-117.

Melnikova, L.M. 2000. A new genus of Bradoriidae (Crustacea) from the Cambrian of Northern Eurasia. Paleontological Journal 34: $180-185$.

Meshkova, N.P. 1985. Novye trubchatye problematiki srednego kembriya Sibiri i Srednej Azii. Trudy Instituta Geologii i Geofiziki, Sibirskoj Otdelnenii Akadmia Nauk SSSR 632: 127-133.

Missarzhevsky, V.V. 1977. Konodonty(?) i fosfatnye problematiki kembriya Mongolii I Sibiri. Trudy Sovmestaya Sovetsko-Mongolskaya Paleontologicheskaya Ekspeditsiya 5: 10-19. 
Nielsen, M.L., J.A. Rasmussen, and D.A.T. Harper. 2017. Sexual dimorphism within the stem-group arthropod Isoxys volucris from the Sirius Passet Lagerstätte, North Greenland. Bulletin of the Geological Society of Denmark 65: 47-58.

Paterson, J.R., J.B. Jago, J.G. Gehling, D.C. García-Bellido, G.D. Edgecombe, and M.S.Y. Lee. 2008. Early Cambrian arthropods from the Emu Bay Shale Lagerstätte, South Australia. In Advances in trilobite research, eds. I. Rábano, R. Gozalo and D. GarcíaBellido. Instituto Geológico y Minero de España, Madrid, Cuadernos del Museo Geominero 9: 319-325.

Peel, J.S. 2015. Bromalites from the Cambrian (Series 2 and 3) of North Greenland. GFF 137: 181-194.

Peel, J.S. 2017a. Systematics and biogeography of some early Cambrian (Series 2) bradoriids (Arthropoda) from Laurentia (Greenland). Canadian Journal of Earth Sciences 54: 961-972.

Peel, J.S. 2017b. The oldest pelmatozoan encrusted hardground and holdfasts from Laurentia (Cambrian Series 2-3). GFF 139: 195-204.

Peel, J.S. 2020. The oldest palaeoloricate mollusc (Cambrian Series 2, Stage 4; North Greenland) and its bearing on aculiferan evolution. Bulletin of Geosciences 95: 127-144.

Peel, J.S. 2021. An outer shelf shelly fauna from Cambrian Series 2 (Stage 4) of North Greenland (Laurentia). Journal of Paleontology, Memoir 83: 1-41.

Peel, J.S., and J.R. Ineson. 2011. The Sirius Passet Lagerstätte (Cambrian) of North Greenland. Palaeontographica Canadiana 31: 109-118.

Peel, J.S., and S. Willman. 2018. The Buen formation (Cambrian Series 2) biota of North Greenland. Papers in Palaeontology 4: 381-432.

Peel, J.S., M. Streng, G. Geyer, A. Kouchinsky, and C.B. Skovsted. 2016. Ovatoryctocara granulata assemblage (Cambrian Series 2-Series 3 boundary) of L $\emptyset$ ndal, North Greenland. Australasian Palaeontological Memoirs 49: 241-282.

Poulsen, C. 1932. The Lower Cambrian faunas of East Greenland. Meddelelser om Grønland 87: 1-66.

Qian, Y. 1978. The early Cambrian hyolithids in central and southwest China and their stratigraphical significance. Memoirs of the Nanjing Institute of Geology and Paleontology 11: 1-38.

Raymond, P.E. 1935. Leanchoilia and other mid-Cambrian Arthropoda. Bulletin of the Museum of Comparative Zoology 76: 205-230.

Rozanov, A.Yu. 1986. Problematica of the Early Cambrian. In Problematic fossil taxa, ed. A. Hoffman and M.H. Nitecki, 87-96. New York, N.Y.: Oxford University Press.

Rozanov, A.Yu., and A.Yu. Zhuravlev. 1992. The Lower Cambrian fossil record of the Soviet Union. In Origin and early evolution of the Metazoa, eds. J.H. Lipps and P.W. Signor, 205-282. New York, N.Y.: Plenum Press.

Shu, D. 1990. Cambrian and Lower Ordovician Bradoriida from Zhenjiang, Hunnan and Shaanxi Provinces, 1-90. Xian: Northwest University Press.

Siveter, D.J., and M. Williams. 1997. Cambrian bradoriid and phosphatocopid arthropods of North America. Special Papers in Palaeontology 57: 1-69.

Siveter, D.J., M. Williams, J.S. Peel, and D.J. Siveter. 1996. Bradoriida (Arthropoda) from the early Cambrian of North Greenland. Transactions of the Royal Society of Edinburgh, Earth Sciences 86: $113-121$.

Skovsted, C.B. 2005. A carapace of the bradoriid arthropod Mongolitubulus from the Early Cambrian of Greenland. GFF 127: 217-220.

Skovsted, C.B. 2006. Small shelly fauna from the upper Lower Cambrian Bastion and Ella Island Formations, North-East Greenland. Journal of Paleontology 80: 1087-1112.

Skovsted, C.B., and J.S. Peel. 2001. The problematic fossil Mongolitubulus from the Lower Cambrian of Greenland. Bulletin of the Geological Society of Denmark 48: 135-147.
Skovsted, C.B., G.A. Brock, and J.R. Paterson. 2006. Bivalved arthropods from the Lower Cambrian Mernmerna Formation, Arrowie Basin, South Australia and their implications for identification of Cambrian 'small shelly fossils.' Memoirs of the Association of Australasian Palaeontologists 32: 7-41.

Slater, B.J., S. Willman, G.E. Budd, and J.S. Peel. 2018. Widespread preservation of small carbonaceous fossils (SCFs) in the early Cambrian of North Greenland. Geology 46: 107-110.

Stein, M., J.S. Peel, D.J. Siveter, and M. Williams. 2009. Isoxys (Arthropoda) with preserved soft anatomy from the Sirius Passet Lagerstätte, lower Cambrian of North Greenland. Lethaia 43: 258-265.

Stein, M., G.E. Budd, J.S. Peel, and D.A.T. Harper. 2013. Arthroaspis n. gen., a common element of the Sirius Passet Lagerstätte (Cambrian, North Greenland), sheds light on trilobite ancestry. BMC Evolutionary Biology 13: 99. https://doi.org/10.1186/1471-2148-13-99.

Streng, M., and G. Geyer. 2019. Middle Cambrian Bradoriida (Arthropoda) from the Franconian Forest, Germany, with a review of bradoriids described from West Gondwana and a revision of material from Baltica. PalZ. Paläontologische Zeitschrift 93: 567-591.

Topper, T.P., C.B. Skovsted, G.A. Brock, and J.R. Paterson. 2007. New bradoriids from the lower Cambrian Mernmerna Formation, South Australia: Systematics, biostratigraphy and biogeography. Memoirs of the Association of Australasian Palaeontologists 33: 67-100.

Topper, T.P., C.B. Skovsted, G.A. Brock, and J.R. Paterson. 2011. The oldest bivalved arthropods from the early Cambrian of East Gondwana: systematics, biostratigraphy and biogeography. Gondwana Research 19: 310-326.

Topper, T.P., C.B. Skovsted, D.A.T. Harper, and P. Ahlberg. 2013. A bradoriid and brachiopod dominated shelly fauna from the Furongian (Cambrian) of Västergötland, Sweden. Journal of Paleontology 87: 69-83.

Torsvik, T.H., and L.R.M. Cocks. 2016. Earth history and palaeogeography, 1-317. Cambridge: Cambridge University Press.

Ulrich, E.O., and R.S. Bassler. 1931. Cambrian bivalved Crustacea of the order Conchostraca. Proceedings of the u.s. National Museum 78: $1-130$.

Vannier, J., and J.-Y. Chen. 2000. The Early Cambrian colonization of pelagic niches exemplified by Isoxys (Arthropoda). Lethaia 33: 295-311.

Vasilieva, N.I. 1994. Rannekembriiskaya melkaya rakovinnaya fauna iz skvazhin zapadnoi Yakutii. Paleontologicheskiy Zhurnal 1994 (4): 3-9.

Vasilieva, N.I. 1998. Melkaya rakovinnaya fauna i biostratigrafiya nizhnego kembriya Sibirskoj platformy. Vserossiyskiy Neftyanoy Nauchno-Issledovatel'skiy Geologorazvedochnyy Institut, 1-139. St. Petersburg: VNIGRI.

Vidal, G., and J.S. Peel. 1993. Acritarchs from the Lower Cambrian Buen Formation in North Greenland. Bulletin Gronlands Geologiske Undersøgelse 164: 1-35.

Vinther, J., L. Porras, F.J. Young, G.E. Budd, and G.D. Edgecombe. 2016. The mouth apparatus of the Cambrian gilled lobopodian Pambdelurion whittingtoni. Palaeontology 59: 841-849.

Wallet, E., B. Slater, S. Willman, and J.S. Peel. 2020. Small Carbonaceous Fossils (SCFs) from North Greenland: New light on metazoan diversity in early Cambrian shelf environments. Papers in Palaeontology. https://doi.org/10.1002/spp2.1347.

Walossek, D. 1999. On the Cambrian diversity of Crustacea. In Crustaceans and the biodiversity crisis, Amsterdam, The Netherlands, July 20-24, 1998, vol. 1, eds. F.R. Schram, and J.C. von Vaupel Klein, 3-27. Leiden: Brill Academic Publishers.

Williams, M., D.J. Siveter, and J.S. Peel. 1996. Isoxys (Arthropoda) from the Early Cambrian Sirius Passet Lagerstätte, North Greenland. Journal of Paleontology 70: 947-954. 
Williams, M., D.J. Siveter, L.E. Popov, and J.C. Vannier. 2007. Biogeography and affinities of the bradoriid arthropods: Cosmopolitan microbenthos of the Cambrian seas. Palaeogeography, Palaeoclimatology, Palaeoecology 248: 202-232.

Wrona, R. 2004. Cambrian microfossils from glacial erratics of King George Island, Antarctica. Acta Palaeontologica Polonica 49: $13-56$.

Wrona, R. 2009. Early Cambrian bradoriide and phosphatocopide arthropods from King George Island, West Antarctica: Biogeographic implications. Polish Polar Research 30: 347-377.

Zhai, D., M. Williams, D.J. Siveter, T.H.P. Harvey, R.S. Sansom, S.E. Gabbott, D.J. Siveter, X. Ma, R. Zhou, Y. Liu, and X. Hou. 2019.
Variation in appendages in early Cambrian bradoriids reveals a wide range of body plans in stem-euarthropods. Communications Biology 2: 329. https://doi.org/10.1038/s42003-019-0573-5.

Zhang, X.-G. 2007. Phosphatized bradoriids (Arthropoda) from the Cambrian of China. Palaeontographica (A: Paläozoologie, Stratigraphie) 281: 93-173.

Zhao, F., J.-B. Caron, D.J. Bottjer, S. Hu, Z. Yin, and M. Zhu. 2014. Diversity and species abundance patterns of the early Cambrian (Series 2, Stage 3) Chengjiang Biota from China. Paleobiology 40: 50-69. 